\title{
THE EFFECT OF SOCIO-ECONOMIC ON SOCIAL CAPITAL IN INDONESIA
}

\author{
Ratni Heliati \\ ratni.heliati@fe.unpad.ac.id \\ Tio Riyono \\ Faculty of Economics and Business, Universitas Padjadjaran \\ Jl. Dipati Ukur No.35, Lebakgede, Coblong, \\ Kota Bandung, Jawa Barat 40132
}

received: 2/6/18; revised: 4/8/18; published: 31/12/18

\begin{abstract}
The current world development agenda led to a focus called the 2030 Sustainable Development Goals (SDGs). There were 17 development goals that became the world's commitment to be achieved soon. The results of the consensus in 1995 at the World Summit for Social Development stated that the development must make humans as the center of development. One of the benchmarks for human development was based on the Social Capital index. Various countries had developed the concept of social capital. So far, the capital of the OECD had become the most referenced, such as Canada, Australia and the United Kingdom, as a reference in developing indicators of social capital. This study aimed to prove Lin's theory which stated that assets or economics were directly proportional to the development of social capital. The results showed that economic variables such as GRDP per capita were inversely proportional to social capital. Subsequently social capital was significantly influenced negatively by Indonesia's democracy index and significantly influenced positively by population density.
\end{abstract}

Keywords: SDGs; human development; economic; social capital; socio-economic

\section{INTRODUCTION}

The current development paradigm should have focused on humans as the center of development. This was agreed by the world in Copenhagen at the World Summit for Social Development meeting in 1995. The forum was attended by 117 leaders of the country and resulted in an agreement that the development paradigm must make humans the subject of development. The United Nations Development Program said (in Shah, 2011):

"Human development is about much more than the rise or fall of national incomes. It is about creating an environment in which people can develop their full potential and lead productive, creative lives in accord with their needs and interests. People are the real wealth of nations. Development is thus about expanding the choices people have to lead lives that they value. And it is thus about much more than economic growth, which is only a means - if a very important one - of enlarging people's choices."

The Organization for Economic Co-operation and Development (2001) added that human welfare could be measured through three things (see Figure 1), namely: natural capital, physical capital, and human capital and social capital. Social capital reflects the application of norms and refers to norms and networks that can be used to create cooperation between communities within groups and between groups.

So that human development does not only rely on economic growth. Human development can be measured on increasing human capabilities (Sen, 1987). Human capability itself can form social capital so that it is considered a social glue and can encourage other development to run better.

The term social capital was first introduced by Bourdieu in 1972 then after by Coleman in 1988 (Häuberer, 2011 in the Central Bureau of Statistics, 2012). Basically, social capital is inherent in every individual relationship in socializing.

OECD in Keeley (2007) defined social capital as networks together with shared norms, values and understandings that facilitate co-operation or among groups.

Lin (1999) explained the theory of social capital that differences in the participation of individual social capital depended on access as the initial capital that the individual had, such as assets and structural positions in 
the social. Lin described the social capital framework was divided into three parts; Inequality, Capitalization, and Effects (see Figure 2). If illustrated, individuals who have higher economic status can get more access and opportunities to establish networks with various individuals/groups at various levels of economic status but individuals with lower social levels tend to have a limited network environment in a small scope.

Social capital has been ingrained in every Indonesian society. One reflection of social capital is mutual cooperation. One of its forms can be seen during the disaster that happened to this country, such as: the tsunami of Aceh, the Yogya earthquake, and so on. Communities from various groups carry out social actions, such as: raising funds, providing food and nonfood, and assisting in the evacuation process. It's not surprising if social capital is associated with economic development which is measured by socioeconomic variables. Putnam (1993) is the first researcher who succeeded in providing a basis for the study of social capital associated with socioeconomic.

Putnam (1993) started researching on social capital. His book titled "Making Democraz Work" successfully attracted the attention of researchers to discuss more about social capital. In the book, social capital is part of many things discussed in the book. Putnam makes social capital from a concept into a practical reality that can be used as a tool to carry out democracy in Italy (Ferragina, 2013). Putnam explained that democracy and the economy of society could be a bridge to social capital through networking (Putnam, 1995 in BPS, 2012). Practically this illustrates the correlation between social capital and democracy itself.

Dragos \& Leskosek (2003) revealed that social capital was a joint asset in society and that it was originally formed from values that had been built. Each region has different values but social adherence is a value that is considered good by all regions.

In one of Ferragina's (2013) research results stated that socioeconomic variables had an effect on social capital. That the GRDP per capita had a positive effect on social capital. Ferragina also found that the better distribution of income would increase social capital.

Chua (2010) also conducted research on sociostructural influences such as meritocracy, gender, and race on social capital and the labor market. The data used was primary representative data in Singapore. The results showed that social capital could affect labor access only for low jobs. Gould \& Hijzen (2016) found that in the United States, inequality had a negative effect on social capital. Allegedly, the more inequality will reduce the level of public confidence.

Social capital used in this study was in macro analysis level. Basically, social capital has two analysis level (Bhandari and Yasonobu, 2009). (a) Individual level, social capital was measured from individual samples, (b) micro-, meso-, and macro level; social capital was measured from individuals and then aggregated by various method to describe social capital at a greater level of analysis.

\section{METHODS}

Data on the formation of social capital generally differ in each country. The Indonesian Central Bureau of Statistics calculates Social Capital using 3 (three) indicators, namely: indicators of trust and tolerance, reciprocity and joint action, and group and network. The following is a table of indicators of social capital obtained from the 2012 and 2014 Social Capital Statistics Report from the Indonesian Central Bureau of Statistics.

The data consists of 33 Indonesian provinces (not including North Kalimantan) and each has three periods; 2009, 2012, 2014. The data are from the National SocioEconomic Survey (Survei Sosial Ekonomi Nasional) on the 2012 Socio-Culture and Education Module (Modul Sosial Budaya dan Pendidikan) or the 2014 Social Security Module (Hansos Module). Respondents around 70,000 heads of households are scattered in all districts/cities in Indonesia.

This study used multiple regression and the method used was Ordinary Least Square (OLS). Adopting the equation built by Ferragina (2013), researchers used the equation for the econometric model as follows:

$$
\begin{aligned}
\mathrm{SM}_{\mathrm{it}}= & \beta_{0}+\beta_{1} \mathrm{IDI}_{\mathrm{it}}+\beta_{2} \mathrm{GINI}_{\mathrm{it}}+\beta_{3} \text { Density }_{\mathrm{it}}+\beta_{4} \mathrm{HDI}_{\mathrm{it}}+ \\
& \beta_{5} \mathrm{GRDP}_{-} \mathrm{Cap}_{\mathrm{it}}+\beta_{6} \mathrm{LFPR}_{\mathrm{it}}+\mathrm{a}_{\mathrm{i}}+\mathrm{u}_{\mathrm{it}}
\end{aligned}
$$

\begin{tabular}{|c|c|}
\hline $\mathrm{SM}_{\mathrm{it}}$ & : Social Capital \\
\hline & : Indonesian Democracy Index \\
\hline $\mathrm{GINI}_{\text {it }}$ & : Gini Coefficient \\
\hline Density $_{\text {it }}$ & : Population Density \\
\hline & : Human Development Index \\
\hline GRDP_Cap & : GRDP per capita \\
\hline $\begin{array}{l}\mathrm{LFPR}_{\mathrm{it}}^{-} \\
\mathrm{a}_{\mathrm{i}}\end{array}$ & $\begin{array}{l}\text { : Labor Force Participation Rate } \\
\text { : unobserved heterogeneity }\end{array}$ \\
\hline & : idiosyncratic error \\
\hline
\end{tabular}

Which:

\section{RESULT AND DISCUSSION}

Research estimates the socio-economic variables on the social capital variable. The following Table 2 explains the summary of statistic of the variables that will be used as material for analysis in this study.

From the table above, it can be seen that 99 observations consisted of 33 provinces and three years each. The average amount of social capital is 54.86 with a minimum index of 38 and a maximum of only 63.16 .

For more clarity, Graph 1 below is a graph of the correlation of social capital with GRDP per capita.

It is seen that the correlation between the two is negative and keeps falling down from 2009 to 2014. This 
shows that the level of well-being is increasingly eroding the development of social capital development. This needs to be watched out, as the growth of the Indonesian economy shows a positive trend of around $5 \%$ per year since the reform era. Of course this will worry about the condition of social capital formed in society. The government must be optimistic about economic growth but must also pay attention to development capital which is increasingly concerned about its relationship with economic growth. Surely the next step that must be done is to evaluate and improve economic growth in the future in order for Pancasila economics, the populist economy can run optimally.

Following are Graph 2, Graph 3, and Graph 4 which show the distribution of quadrants of social capital index values and GRDP per capita by province.

Interesting findings that DKI Jakarta as the capital city of the province is included in quadrant IV, which means that the province has an economic level above average but has a social capital index below average. This means that there is something wrong with the economic development carried out by Indonesia. Economic improvement is not accompanied by an increase in social capital as a poxy from human development.

The following table 3 is the estimation result using the Fixed Effect Model based on the Hausman test results (see Table 4 in the appendix):

The estimation results use robust variancecovariance matrix (VCE) in Stata software. The use of VCE robust is to overcome the problems of heteroscedasticity and autocorrelation (Arellano, 1987). Based on the estimation results above, R2 shows a value of 0.7 which means that the independent variable is able to explain the variation of social capital by $70 \%$ and the remaining $30 \%$ is explained by other variables outside the model.

The results show that social capital is significantly influenced positively by the Indonesian democracy index and GRDP per capita. This means that the higher the economic level GRDP per capita) of a province, the lower the level of the social capital index is. This means that there is something wrong with the contribution of economic development to the development of human resources. Economic development should be accompanied by human development. Because humans should be the subject of development, which can lead to better development. If so, Lin's theory did not occur in the case study of the Indonesian province.

Not only it is contrary to Lin's Theory, but the results are also contrary to the economy which has been the guide of Indonesia. Pancasila economy should be able to increase or strengthen relations in the community as reflected in the social capital index because these values are from Indonesian authentic ancestors.

Furthermore, social capital is significantly influenced negatively by population density. This can mean that the higher population, the lower the participation rate of social capital is.

The author also estimates the constants for each of the available provinces in Graph 5 (see attachment). From the estimation results, East Kalimantan and DKI Jakarta have the highest and lowest constant values. The high and low constants indicate differences in the magnitude of influence among provinces in Indonesia. So, for the province of East Kalimantan, the influence of the independent variables on dependent is very large while for DKI Jakarta has a low influence. In addition, it can be seen that there is a pattern where provinces with high constants will push the province into quadrant I (see Graph 2, Graph 3, and Graph 4). This is getting better because it means that the high level of the economy is accompanied by high social capital.

Indonesia must be able to learn from countries in Europe. How the level of welfare of a region has a positive impact on the development of human capital as has been done on a research by Ferragina (2013).

\section{CONCLUSSION}

Cases in Indonesia are different from Europe. The higher the level of GRDP per capita actually erodes social capital. Therefore, economic development to date has not succeeded in making humans the subject of development.

This study also analyzes the relationship of macro variables to the level of social capital of provinces in Indonesia. The results show that social capital is significantly affected negatively by the Indonesian democracy index and GRDP per capita. Furthermore, social capital is significantly influenced positively by population density.

\section{REFERENCES}

Arellano, M. 1987. Practitioners Corner: Computing Robust Standard Errors for Within-groups Estimators, Oxford bulletin of Economics and Statistics. Wiley Online Library, 49(4), pp. 431-434. Badan Pusat Satistik. 2012. Statistik Modal Sosial 2012. Bhandari, H. and Yasunobu, K. 2009. What is Social Capital? A Comprehensive review of the concept. Asian Journal of Social Sciences, 37(3). doi:10.1163/156853109x436847

Chua, V. 2010. Social Capital and Inequality in Singapore. Available at: https://tspace.library. utoronto.ca/handle/1807/26353.

Dragos, S. and Leskosek, V. 2003. Social Inequality and Social Capital, p. 101.

Ferragina, E. 2013. The socio-economic determinants of social capital and the mediating effect of history: Making Democracy Work revisited, International Journal of Comparative Sociology, 54(1), pp. 48-73.

Gould, E. D. and Hijzen, A. 2016. Growing Apart, 
Losing Trust? The Impact of Inequality on Social Capital, IMF Working Papers, p. 47.

Häuberer, J. 2011. Social Capital Theory. Towards a. Springer.

Keeley, B. 2007. How what you know shape your life. OECD Publishing. Available at: http://dx.doi. org//10.1787/9789264029095-en.

Lin, N. 1999. Building a network theory of social capital, in Social capital. Routledge, pp. 3-28.

Organisation for Economic Co-operation and Development (OECD). 2001. The Well-Being of Nations: The Role of Human and Social Capital, The Role of Human and Social Capital, (Perancis: OECD).

Putnam, R. D. 1993. Making Democracy Work. Civil
Traditions in modern Italy, Princeton University Press. doi: 10.2307/2620793.

Putnam, R. D. 1995. Bowling alone: America's declining social capital, in. Available at: http:// www.saddleback.edu/faculty/agordon/documents/ Bowling_Alone.pdf.

Sen, A. 1987. The Standard of Living. Edited by G. Hawthorne. Cambridge: Cambridge University Press. Available at: http://www.amazon.com/ Standard-Living-Tanner-Lectures-Values/ $\mathrm{dp} / 0521368405 / \mathrm{ref}=$ sr_1_1? $=$ =books\&ie=UTF8 \&qid $=1310680161 \& \mathrm{sr}=1-1$.

Shah, A. 2011. Poverty Around The World, Global Issues.

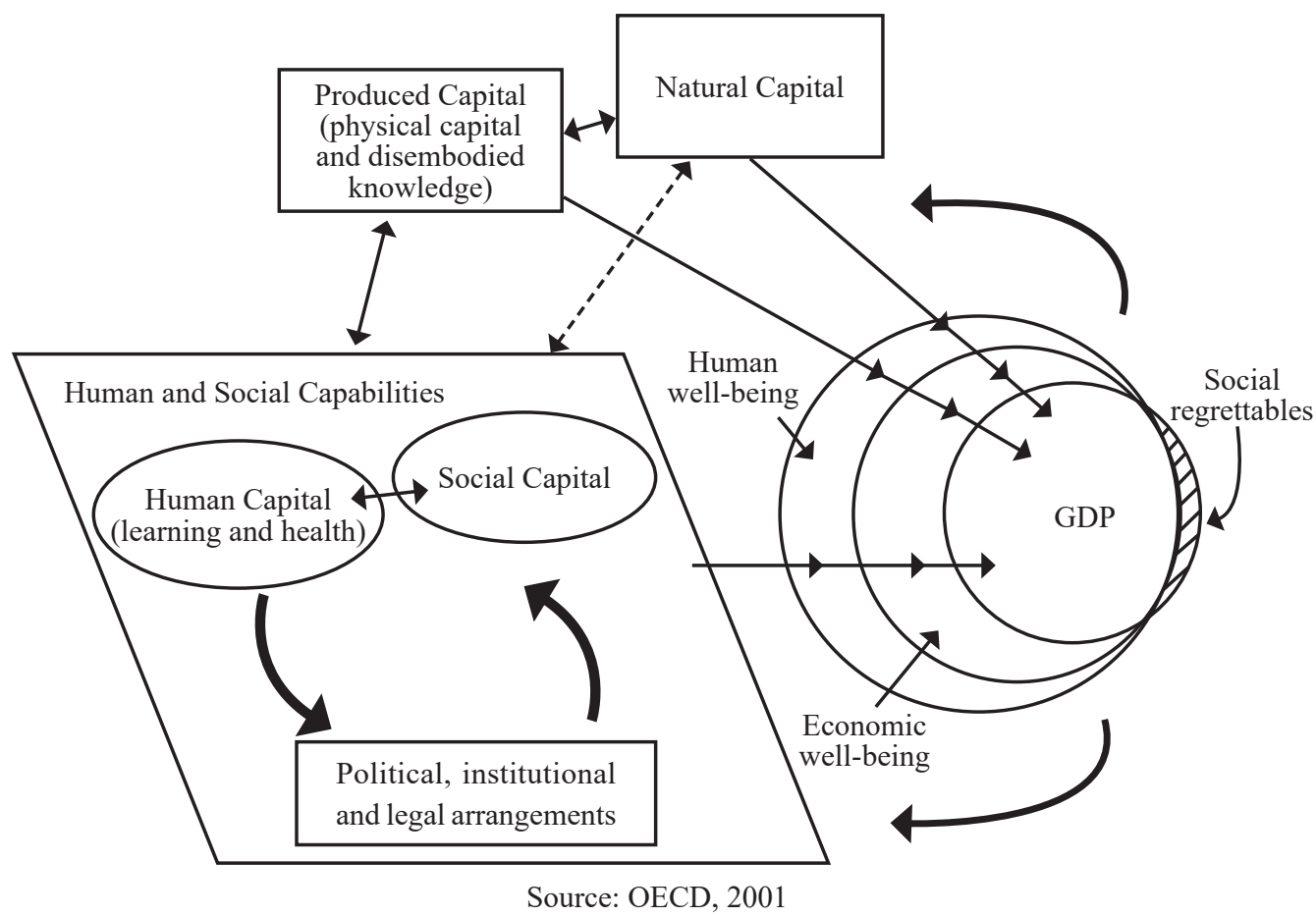

Figure 1. Human Welfare Input Indicators and their Linkages

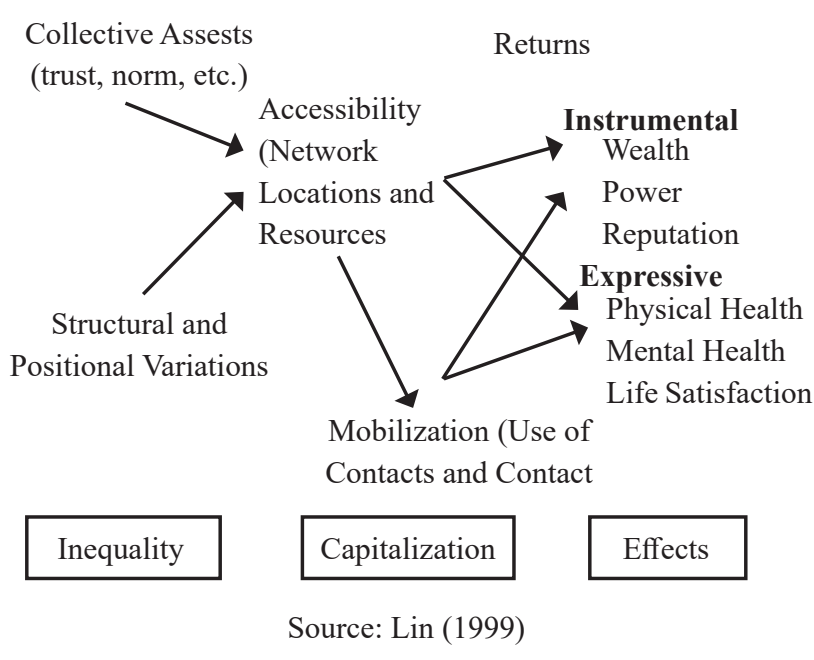

Figure 2. Social Capital Framework
Modified Wald test for groupwise heteroskedasticity in fixed effect regression model

H0: sigma (i)^2 $=\operatorname{sigma}^{\wedge} 2$ for all $\mathrm{i}$

Chi2 (33) $=1886.55$

Figure 3. Heteroskedasticity Test Result

Wooldridge test for autocorrelation in panel data H0: no first-order autocorrelation

$$
\begin{aligned}
& F(1,32)=6.074 \\
& \text { Prob }>F=0.0193
\end{aligned}
$$

Figure 4. Autocorrelation Test Result 
2009

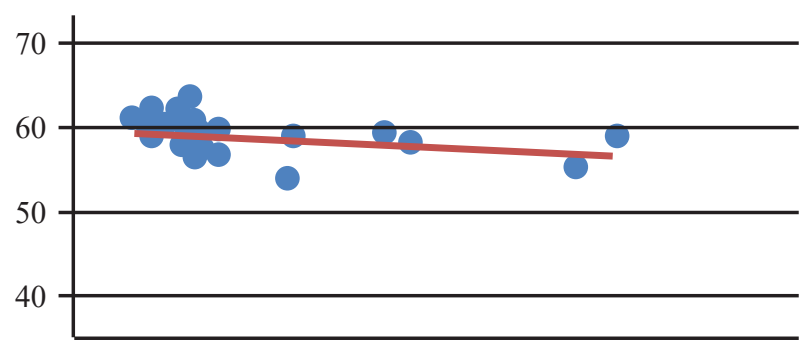

2014

GRDP_percapita

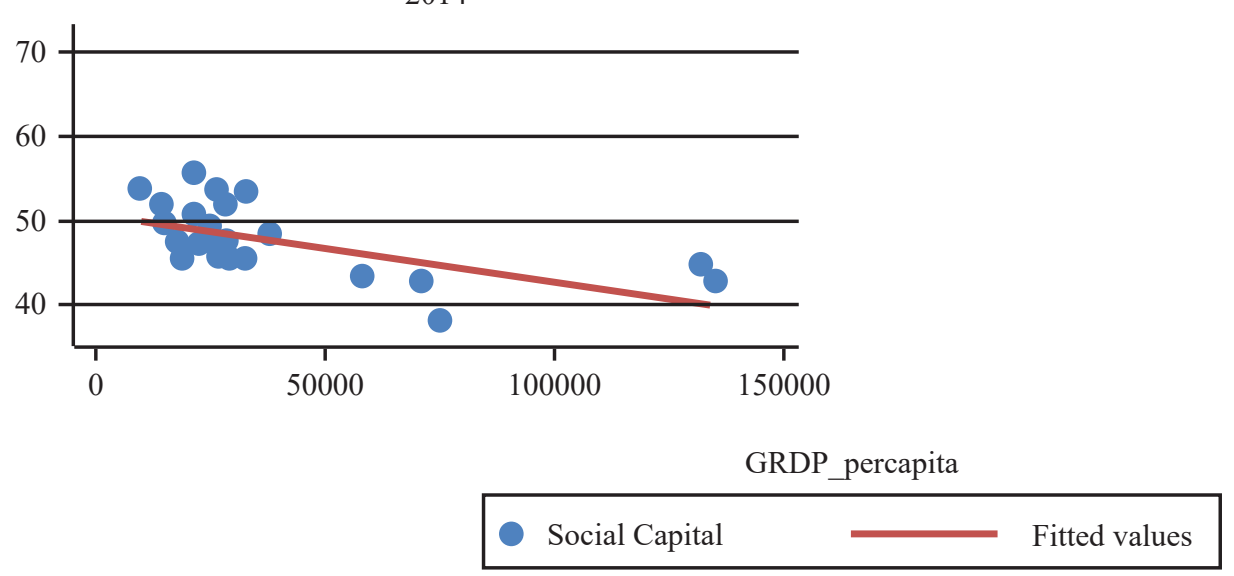

2012

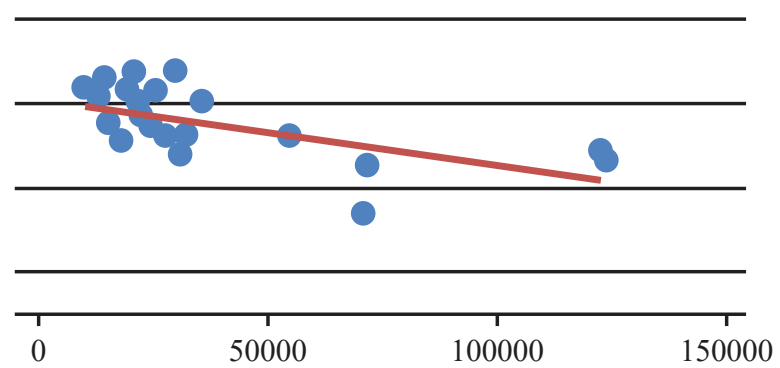

Graph 1. Correlation of Social Capital with GRDP per Capita

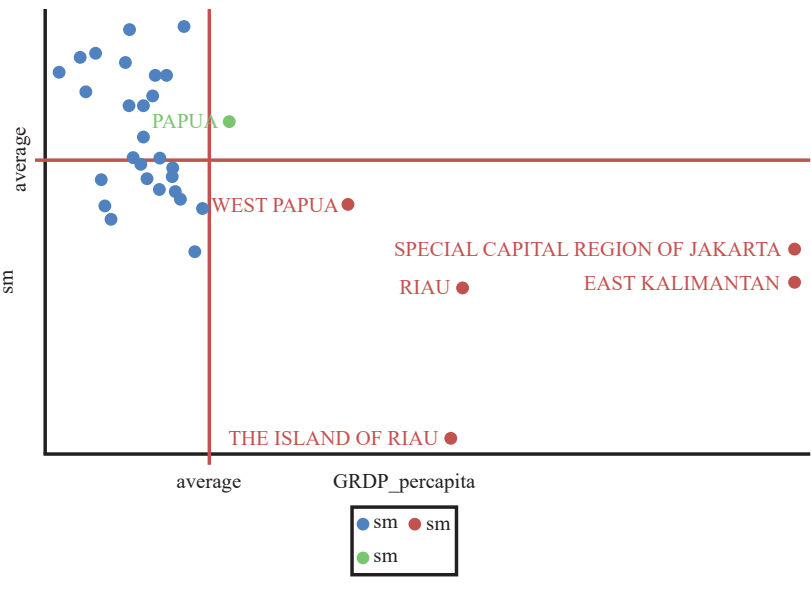

Graph 2. Province's Quadrant Position of 2009

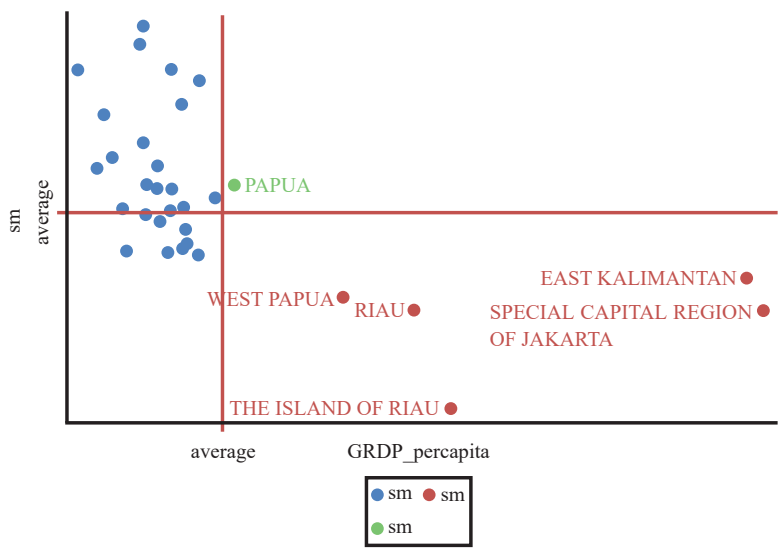

Graph 3. Province's Quadrant Position of 2012

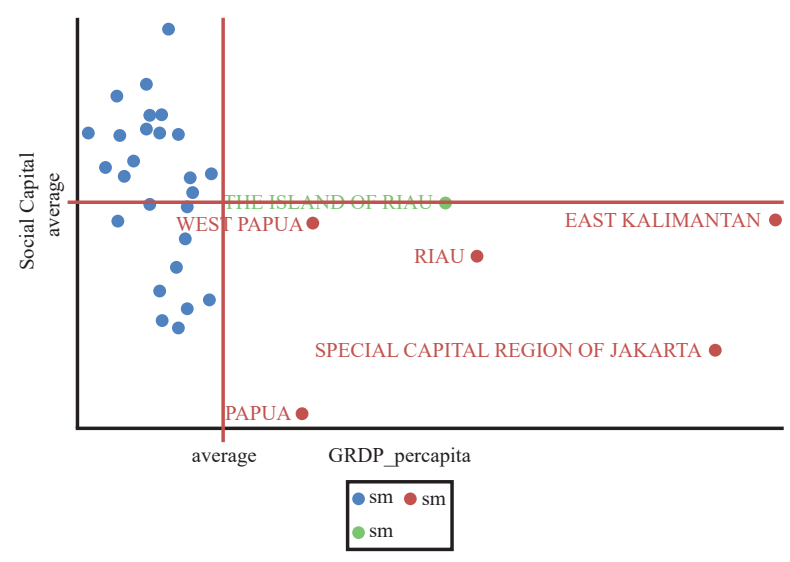

Graph 4. Province's Quadrant Position of 2014 


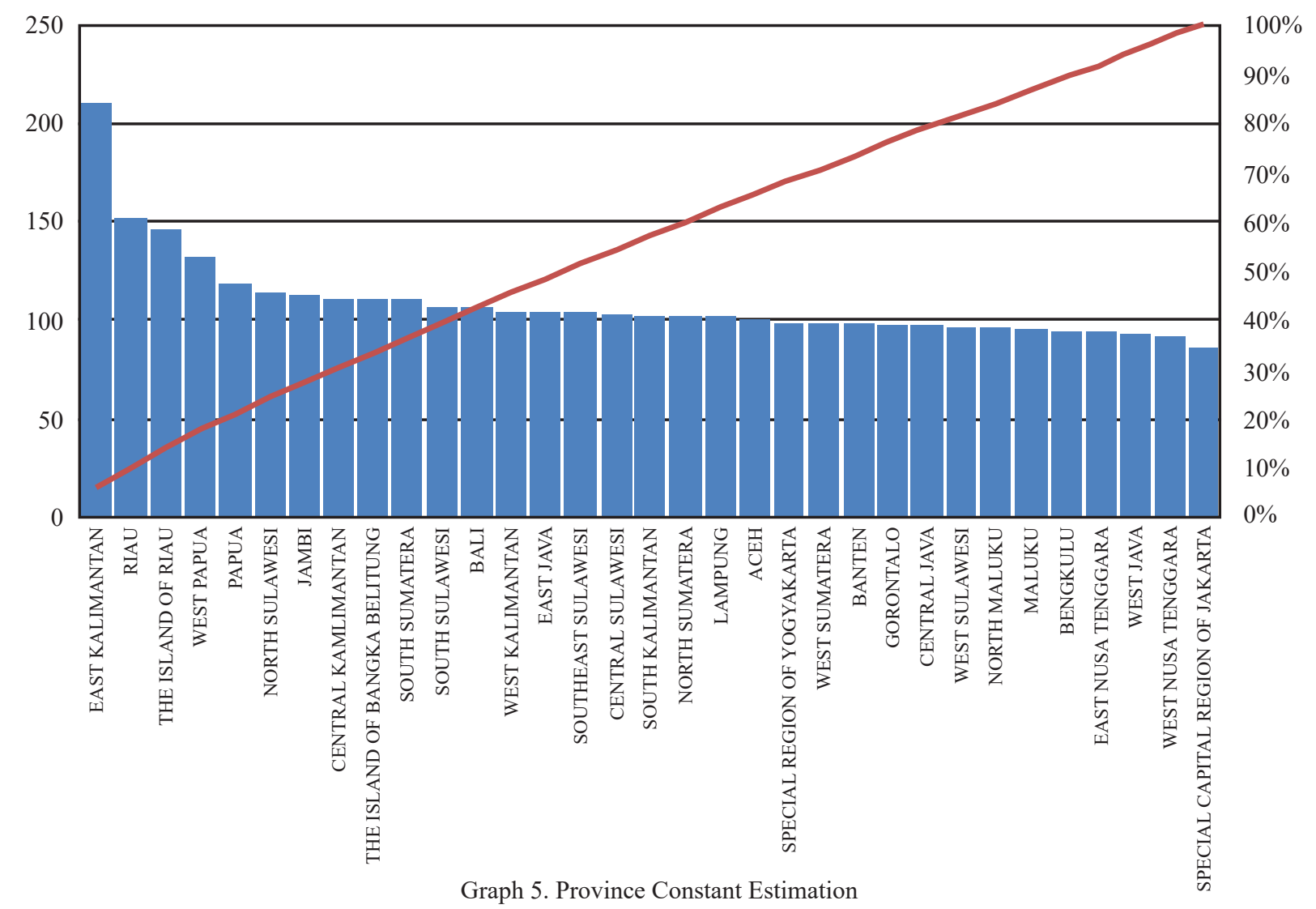

Table 1. Indicators of Social Capital

\begin{tabular}{|c|c|c|c|}
\hline Indicator & Factor & Variable $(2009,2012)$ & Variable (2014) \\
\hline \multirow{12}{*}{$\begin{array}{l}\text { Trust and } \\
\text { Tolerance }\end{array}$} & Trust in figure & Trust in religious figure & Trust in religious figure \\
\hline & & Trust in village/kelurahan authority & Trust in village/kelurahan authority \\
\hline & & - & Trust in public figure \\
\hline & Trust in & Trust in neighbor for childcare (age $0-12$ ) & Trust in neighbor for childcare (age $0-12$ ) \\
\hline & neighbor & Trust in neighbor for house sitting & Trust in neighbor for house sitting \\
\hline & Religion & Response to other religion's activities & Response to other religion's activities \\
\hline & Tolerance & - & Response to building worship place of other religion \\
\hline & & - & Child befriends people with different religion \\
\hline & & - & Child marries people with different religion \\
\hline & Tribe/Clan & Response to other tribe's/clan's activities & Response to other tribe's/clan's activities \\
\hline & Tolerance & - & Child marries people from different tribe/clan \\
\hline & & - & Child befriends people from different tribe/clan \\
\hline \multirow{6}{*}{$\begin{array}{c}\text { Reciprocity } \\
\text { and Joint } \\
\text { Action }\end{array}$} & Reciprocity & - & Ease of getting help \\
\hline & & - & Willing to help neighbor in need \\
\hline & Joint Action & Participation in religious social activities & Participation in religious activities \\
\hline & & Participation in activities for public interest & Participation in activities for residents' interest \\
\hline & & Participation in social community activities & Participation in social community activities \\
\hline & & Participation in joint activities to help residents & Participation in joint activities to help residents \\
\hline \multirow{6}{*}{$\begin{array}{l}\text { Group and } \\
\text { Network }\end{array}$} & Participation & - & Frequency of resident meeting in the area \\
\hline & in group & - & Decision making in the area \\
\hline & & - & Joining resident meeting \\
\hline & & - & Usually give opinion/advice in a meeting \\
\hline & Network & - & Number of group/organization joined \\
\hline & & - & Position in a group \\
\hline
\end{tabular}


Table 2. Statistic Summary

\begin{tabular}{lccccc}
\hline VARIABLES & $\mathrm{N}$ & mean & $\mathrm{sd}$ & $\min$ & $\max$ \\
\hline sm & 99 & 54.87 & 5.964 & 38 & 63.16 \\
gini & 99 & 0.364 & 0.0449 & 0.269 & 0.459 \\
idi & 99 & 68.72 & 6.386 & 54.02 & 84.70 \\
hdi & 99 & 68.72 & 4.334 & 55.55 & 78.39 \\
grdp_percapita & 99 & 32,897 & 27,004 & 9,026 & 136,312 \\
density & 99 & 684.4 & 2,432 & 6 & 15,173 \\
lfpr & 99 & 69.74 & 3.952 & 60.33 & 80.54 \\
\hline
\end{tabular}

Table 4. Hausman Test Result

Coefficients

\begin{tabular}{lcccc}
\hline \multicolumn{5}{c}{ Coefficients } \\
& (b) & (B) & (b-B) & $\begin{array}{c}\text { sqrt } \\
\left(\operatorname{diag}\left(V_{-} b-\right.\right. \\
\text { V_B })\end{array}$ \\
& fe & re & Difference & \multicolumn{1}{c}{ S.E } \\
\hline idi & -.4550924 & -.368721 & -.0863714 & .0953528 \\
gini & -17.41737 & -8.447342 & -8.970032 & 20.7207 \\
density & .0087878 & .0003139 & .0084739 & .0032867 \\
hdi & .0416427 & .483176 & -.4415333 & .2977118 \\
gdrp per-cap & -.0010565 & -.0000967 & -.0009598 & .000246 \\
1fpr & .1242705 & .1394079 & -.01513 & .4474309 \\
\hline
\end{tabular}

Tabel 3. Social Capital Estimation

\begin{tabular}{lc}
\hline VARIABLES & Social Capital \\
\hline IDI & $-0.455^{* * *}$ \\
& $(0.0913)$ \\
GINI & -17.42 \\
& $(20.00)$ \\
Density & $0.00879 * * *$ \\
& $(0.00176)$ \\
HDI & 0.0416 \\
& $(0.248)$ \\
GRDP_CAP & $-0.00106 * * *$ \\
LFPR & $(0.000193)$ \\
& 0.124 \\
Constant & $(0.317)$ \\
& $109.7 * * *$ \\
Observations & $(32.56)$ \\
Number of id & 99 \\
R-squared & 33 \\
\hline Robust standard errors in parentheses \\
$* * *$ p $<0.01, * * p<0.05, * p<0.1$ \\
\end{tabular}


Table 5. Estimation Result + Dummy Province Result

\begin{tabular}{|c|c|}
\hline VARIABLES & $\mathrm{Sm}$ \\
\hline \multirow[t]{2}{*}{ idi } & $-0.455^{* * *}$ \\
\hline & $(0.0913)$ \\
\hline \multirow[t]{2}{*}{ gini } & -17.42 \\
\hline & $(18.80)$ \\
\hline \multirow[t]{2}{*}{ density } & $0.00879 * * *$ \\
\hline & $(0.00183)$ \\
\hline \multirow[t]{2}{*}{ hdi } & 0.0416 \\
\hline & $(0.262)$ \\
\hline \multirow[t]{2}{*}{ grdp_percapita } & $-0.00106^{* * *}$ \\
\hline & $(0.000196)$ \\
\hline \multirow[t]{2}{*}{ lfpr } & 0.124 \\
\hline & $(0.314)$ \\
\hline \multirow[t]{2}{*}{$\mathrm{ACEH}$} & $101.9 * * *$ \\
\hline & $(32.27)$ \\
\hline \multirow[t]{2}{*}{ BALI } & $107.1 * * *$ \\
\hline & $(36.30)$ \\
\hline \multirow[t]{2}{*}{ BANTEN } & $99.01 * * *$ \\
\hline & $(32.82)$ \\
\hline \multirow[t]{2}{*}{ BENGKULU } & $95.40 * * *$ \\
\hline & $(34.63)$ \\
\hline \multirow[t]{2}{*}{ SPECIAL REGION OF YOGYAKARTA } & $99.59 * * *$ \\
\hline & $(35.39)$ \\
\hline \multirow[t]{2}{*}{ SPECIAL CAPITAL REGION OF JAKARTA } & $86.50 * * *$ \\
\hline & $(29.86)$ \\
\hline \multirow[t]{2}{*}{ GORONTALO } & $98.98 * * *$ \\
\hline & $(32.05)$ \\
\hline \multirow[t]{2}{*}{ JAMBI } & $113.0^{* * *}$ \\
\hline & $(33.34)$ \\
\hline \multirow[t]{2}{*}{ WEST JAVA } & $94.03 * * *$ \\
\hline & $(31.89)$ \\
\hline \multirow[t]{2}{*}{ CENTRAL JAVA } & $98.86 * * *$ \\
\hline & $(33.35)$ \\
\hline \multirow[t]{2}{*}{ EAST JAVA } & $105.5 * * *$ \\
\hline & $(33.51)$ \\
\hline \multirow[t]{2}{*}{ WEST KALIMANTAN } & $105.7 * * *$ \\
\hline & $(34.15)$ \\
\hline \multirow[t]{2}{*}{ SOUTH KALIMANTAN } & $103.2 * * *$ \\
\hline & $(33.76)$ \\
\hline \multirow[t]{2}{*}{ CENTRAL KALIMANTAN } & $110.7 * * *$ \\
\hline & $(34.65)$ \\
\hline
\end{tabular}

\begin{tabular}{|c|c|}
\hline EAST KALIMANTAN & $\begin{array}{l}211.4 * * * \\
(42.79)\end{array}$ \\
\hline THE ISLAND OF BANGKA BELITUNG & $\begin{array}{l}110.7 * * * \\
(33.15)\end{array}$ \\
\hline THE ISLAND OF RIAU & $\begin{array}{l}147.0 * * * \\
(37.90)\end{array}$ \\
\hline LAMPUNG & $\begin{array}{l}102.9 * * * \\
(33.87)\end{array}$ \\
\hline MALUKU & $\begin{array}{l}95.77 * * * \\
(32.31)\end{array}$ \\
\hline NORTH MALUKU & $\begin{array}{l}97.78 * * * \\
(32.79)\end{array}$ \\
\hline WEST NUSA TENGGARA & $\begin{array}{l}92.91 * * * \\
(32.22)\end{array}$ \\
\hline EAST NUSA TENGGARA & $\begin{array}{l}94.72 * * * \\
(34.25)\end{array}$ \\
\hline PAPUA & $\begin{array}{l}118.8^{* * *} \\
(34.98)\end{array}$ \\
\hline WEST PAPUA & $\begin{array}{l}132.8^{* * *} \\
(35.11)\end{array}$ \\
\hline RIAU & $\begin{array}{l}153.0 * * * \\
(36.16)\end{array}$ \\
\hline WEST SULAWESI & $\begin{array}{l}97.80 * * * \\
(32.74)\end{array}$ \\
\hline SOUTH SULAWESI & $\begin{array}{l}108.0 * * * \\
(32.39)\end{array}$ \\
\hline CENTRAL SULAWESI & $\begin{array}{l}104.7 * * * \\
(34.07)\end{array}$ \\
\hline SOUTHEAST SULAWESI & $\begin{array}{l}104.8^{* * *} \\
(34.38)\end{array}$ \\
\hline NORTH SULAWESI & $\begin{array}{l}114.7 * * * \\
(33.48)\end{array}$ \\
\hline WEST SUMATERA & $\begin{array}{l}99.36^{* * *} \\
(33.40)\end{array}$ \\
\hline SOUTH SUMATERA & $\begin{array}{l}110.5 * * * \\
(34.23)\end{array}$ \\
\hline NORTH SUMATERA & $\begin{array}{l}103.0 * * * \\
(34.58)\end{array}$ \\
\hline Observations & 99 \\
\hline R-squared & 0.7 \\
\hline
\end{tabular}

